\title{
DIRECTIONS OF IMPROVEMENT OF HUMAN RESOURCES POLICY IN LOCAL GOVERNMENT IN UKRAINE
}

\section{НАПРЯМИ УДОСКОНАЛЕННЯ КАДРОВОЇ ПОЛІТИКИ В ОРГАНАХ МІСЦЕВОГО САМОВРЯДУВАННЯ В УКРАЇНІ}

\section{Ihor Shpektorenko ${ }^{1}$}

DOI: https://doi.org/10.30525/978-9934-26-049-0-4

\begin{abstract}
The author examines the dependence and impact of the distribution of powers of local governments, the content of their functions, activities and tasks in the context of the formation of professional competence, professionalism and professional mobility of officials as subjects of labor and activity. The main idea of the article is that in Ukraine there is now a separation of local government from state. This exacerbates the problem of redistribution and separation of functions and, accordingly, tasks and powers, which will be reflected in the substantive characteristics of professionalism and professional mobility of officials as their current professional qualities. The subject of the study is the impact of decentralization, the process of transformation of public administration on the process of professionalization of local government officials.

The research methodology consists in the integrated involvement of the following research methods: methods of analysis: system analysis; complex analysis, decompositions, sequential comparison method and logical and dynamic methods; structural and functional method to clarify the basic concepts. The article uses construction methods: system method; methods of forecasting and planning processes, modeling method; method of structuring goals. The abstract-logical method was used for theoretical generalization and formulation of conclusions.

The purpose of the study is to develop areas for improving personnel policy in local governments in Ukraine, through meaningful disclosure of the
\end{abstract}

\footnotetext{
${ }^{1}$ Doctor of Science in Public Administration, Professor,

Professor of the Department of Public Administration and Local Self-Government, Dnipropetrovsk Regional Institute of Public Administration of the National Academy of Public Administration, Ukraine
} 
concepts of «human resources», «professional potential», «professionalism», «professional mobility» in relation to the professional group of local government officials, outlines problems and possible approaches to improving these potentials in Ukrainian realities. The result of the article is a set of main areas of development and improvement of personnel policy and activities of the structural unit for staff development in local government, which are designed to develop professional mobility as a modern top quality of officials.

The conclusions indicate the need to improve the forms and methods of working with local government officials, the reserve of personnel, the use of mechanisms and principles of formation and implementation of personnel policy in local governments, creating organizational conditions, addressing the issue of rational selection, placement and professional development personnel through a comprehensive assessment of staff, in particular professional potential, including the activity expression of the latter.

The time has come for radical changes in the content of training, retraining and advanced training, self-education of local government officials, which would correspond to the new powers and competencies of local governments, based on professional potential and suitability, aimed at achieving high professionalism and professional mobility, including high professional culture.

From the author's point of view, it is necessary to provide for the allocation of funds in local budgets for the training of municipal employees in the amount of at least $4 \%$ of the salary fund. It is also necessary to strengthen the protection of local government officials from involvement in election campaigns, from unjustified dismissals of officials, in particular in cases where there is a renewal of politicians and leadership of local governments.

\section{1. Вступ}

Актуальність даної статті обумовлена тим, що місцеве самоврядування є одним 3 невід'ємних атрибутів громадянського суспільства й інноваційним суб'єктом державотворення сучасних економічно й соціально розвинутих країн світу. На сьогоднішній день це єдино можлива демократична та раціональна модель влади на місцях, яка не може бути ефективною без забезпечення в ній такого ж ступеня ефективності роботи з кадрами з метою їхньої професіоналізації.

Аналіз практичної реалізації кадрової роботи в сучасній Україні показує, що реалізація стратегічного завдання, спрямованого на 
реформування служби в органах місцевого самоврядування з метою підвищення іiі ефективності, продуктивності, віддачі, потребує зосередження основних зусиль науковців та практиків на розв'язанні ряду ключових завдань, від позитивних результатів реалізації яких залежить забезпечення в цілому стабільного та безперервного розвитку служби в органах місцевого самоврядування.

Місцеве самоврядування виступає в якості адміністративної організації по забезпеченню життєдіяльності населення муніципальних утворень відповідно до державних соціальних стандартів і загального політичного курсу органів державної влади, як інститут громадянського суспільства, що протистоїть всевладності держави, і водночас це - інститут публічної влади, що має низку спільних з державою ознак і виконує відповідні державні функції [9]. Аналіз конституційних положень вказує, що місцеве самоврядування як об'єкт конституційно-правового регулювання виступає в якості: по-перше, основи конституційного ладу України та найважливішого принципу організації і функціонування публічної влади в держав; по-друге, специфічної форми народовладдя; по-третє, права жителів на самостійне вирішення питань місцевого значення; по-четверте, професійного інституту. Розгляд актуального нині феномену місцевого самоврядування саме 3 цих сторін надає йому характеру комплексності та всеосяжності, виводячи на якісно новий рівень дослідження проблеми його ефективної дії через професіоналізацію посадових осіб.

По суті в Україні зараз відбувається відокремлення місцевого управління від державного, що гостро ставить проблему перерозподілу та розмежування завдань і повноважень і, відповідно, специфічних завдань, функцій, компетенцій. Основними завданнями діяльності є залучення населення до участі у вирішенні питань місцевого та загальнодержавного значення; створення об’єднаних територіальних громад, управління комунальною власністю, забезпечення комплексного соціально-економічного розвитку певної території; надання соціальних послуг населенню; забезпечення законності, правопорядку, охорона прав, свобод і законних інтересів громадян; соціальний захист; захист прав місцевого самоврядування [9]. Розуміння зазначених вище основних завдань та специфічних функцій є обов'язковим у зв'язку з тим, що через них розкривається аксіологічне та діяльнісне призначення місцевого самоврядування у суспільстві, зміст і напрями 
професійної діяльності посадових осіб місцевого самоврядування та позапрофесійної діяльності депутатів місцевих рад.

Проте практика реалізації численних законних та підзаконних актів України за весь період іiі незалежності вказує на віддаленість бажаної перспективи. Чинне законодавство України про місцеве самоврядування, відсутність контролю за кадровими процесами є найголовнішими передумовами неефективного кадрового забезпечення органів місцевого самоврядування.

Мета дослідження: розробка напрямів удосконалення кадрової політики в органах місцевого самоврядування в Україні через змістовне розкриття понять «кадровий потенціал», «професійний потенціал», «професіоналізм», «професійна мобільність» у відношенні до професійної групи посадових осіб місцевого самоврядування. Науково-дослідницькими завданнями є: визначити основний зміст та напрями сучасних трансформацій у сфері публічного управління в Україні, 3 використанням сучасних поглядів на процес професійного розвитку та становлення персоналу запропонувати комплекс напрямів з удосконалення роботи з кадрами в органах місцевого самоврядування в Україні.

Методологія дослідження полягає в інтегрованому залученні таких методів наукового дослідження: методи аналізу: системний аналіз (у дослідженні процесів та явищ як певних систем); комплексний аналіз, декомпозиції, метод послідовного зіставлення та логічний та динамічний методи (в аналізі сучасних проблем місцевого самоврядування та професіоналізації в них); структурно-функціональний метод для уточнення основних понять, у тому числі поняття «професійна мобільність», під час вивчення об'єктивних факторів та умов професійного середовища, які забезпечують формування професійно мобільного персоналу. У статті використано методи побудови: системний метод; методи прогнозування та планування процесів, метод моделювання; метод структуризації цілей (з метою конкретизації напрямів удосконалення роботи з кадрами в органах місцевого самоврядування). Абстрактно-логічний метод було використано для теоретичного узагальнення й формулювання висновків.

Логіка подання дослідженого матеріалу полягає у розкритті основних напрямів реформування місцевого самоврядування в Україні на тлі сучасних проблем у кадровому забезпеченні органів місцевого самоврядування 
визначити напрями іiі удосконалення, головним чином, через формування в персоналі опорних якостей процесу професіоналізації: «професійної компетентності», «професійного потенціалу», «професіоналізму», «професійної мобільності». Професійна мобільність розуміється як здатність та здібність особистості швидко та результативно набувати компетентнісних якостей (професійна компетентність, професійна культура, професійно важливі якості, професійна научуваність, професійний досвід) у їх зв'язку з комплексом ціннісно-оріснтаційних якостей.

\section{2. Концептуалізація напрямів удосконалення кадрової роботи в органах місцевого самоврядування}

Формування та раціональне використання кадрів - важлива й актуальна проблема публічного управління. Тривалий час ії вирішували однобічно, переважно як до організаційно-управлінського завдання в процесі реалізації функції управління - організації. Необхідність розробки нової кадрової політики, кадрового забезпечення органів місцевого самоврядування в Україні об’єктивно випливає зі змісту завдань і функцій держави.

Формування програм кадрової політики в органах місцевого самоврядування - це не поглиблення адміністративно-бюрократичних тенденцій, а удосконалення демократичних та публічних підходів, засобів та інструментів управління системою служби в органах місцевого самоврядування. Публічна служба - це публічна взаємодія та довіра. Кожна посадова особа місцевого самоврядування має ставити відданість Конституції, законам та етичним нормам вище за приватний інтерес.

Становлення кадрової політики в органах місцевого самоврядування України відбувається в умовах зміни парадигми суспільного розвитку, типу культури, духовно-моральних орієнтирів, які набирають ринкового, демократичного змісту. У зв'язку з цим дедалі більшого значення набуває роль особистісного фактора, наукових професійних знань та компетентності, професіоналізму та професійної мобільності персоналу органів місцевого самоврядування загалом.

Багато років тому саме життя поставило ключове завдання істотного оновлення управлінської еліти, але зробити це в українських умовах виявилося складно. Управлінська еліта в силу багатьох причин має слабкі можливості самореалізації, самооновлення на засадах конкурсного відбору та конкуренції. Професія посадової особи місцевого самовряду- 
вання не працює як соціальний ліфт через недосконалу кадрову політику, непотичні зв'язки, слабку привабливість, формалізм і безвідповідальність та відсутність контролю у ії здійсненні. Тому доречні пропозиції, наприклад, «активізувати, розвивати внутрішній духовно-інтелектуальний потенціал посадових осіб місцевого самоврядування усіх рівнів»; сподівання на те, що посадові особи «мають стати свідомими провідниками ідеології та політики українського державотворення, каталізаторами національного, економічного, політичного, духовно-культурного розвитку»; а люди, які обираються і призначаються на керівні посади, повинні сприяти консолідації нації, мати відповідні ідейні, моральні, психологічні, фахові якості» [17, с. 22], вже третє десятиліття залишатимуться реалізованими лише частково. Тому завдання переформатувати посадових осіб місцевого самоврядування на авангард управлінської національної еліти залишається досі актуальним.

Надзвичайно важливо, щоб управлінська еліта, що працює в органах місцевого самоврядування, була глибоко національною та патріотичною не на словах, а за своїми ідейними переконаннями та практичними справами. Це означає, щоб на службу потрапляли лише ті, управлінські рішення яких будуть спрямовані на користь України та iii народу, працювали на зміцнення економічного, оборонного, соціально-культурного потенціалу. Крім цього потрібен високий рівень професіоналізму та професійної мобільності як найважливіших умов кадрової політики в органах місцевого самоврядування.

Процес децентралізації влади в Україні передбачає передачу ряду основних та специфічних функцій управління в різних напрямах гуманітарної, соціальної, економічної, бюджетно-фінансової, інвестиційної сфер, міжнародних відносин 3 центру на місцевий рівень. Тому такі принципово нові підходи до вирішення управлінських проблем перехідного суспільства, зорієнтовано на автономізацію та менеджмент управлінської діяльності в органах місцевого самоврядування, вимагають корекції змісту, напрямів кадрової політики в органах місцевого самоврядування України, переосмислення ролі та місця служб розвитку персоналу, підготовки управлінських кадрів, які володіють вже не тільки комплексом сучасних професійних компетентностей, а й практичною придатністю до роботи, мають професіоналізм та професійну мобільність. При цьому дуже важливо створити єдину систему 
та нормативно-правову базу професійного розвитку (професійного добору, орієнтації, адаптації, активізації, мотивації, оцінювання, підготовки, перепідготовки та підвищення кваліфікації, професійного виховання) посадових осіб місцевого самоврядування, забезпечити визначення та закріплення їх функцій та впливу на процеси професійного життя посадових осіб, збалансованості у здійсненні ефективної політики суспільного розвитку, надання адміністративних послуг населенню, дотримання та захисту конституційних прав і свобод громадян.

Виходячи з потреби забезпечення формування та розвитку кадрового складу за рахунок зменшення плинності та структурної оптимізації служби в органах місцевого самоврядування, надання більшої зорієнтованості на соціальне служіння та надання управлінських послуг, ключовими оріснтирами реформування системи кадрового забезпечення служби в органах місцевого мають бути: підняття в суспільстві престижу служби в органах місцевого самоврядування, досягнення максимальної об' єктивності, відкритості та прозорості у процесах відбору, прийому та професійного розвитку посадових осіб на основі їх ділових, професійних та морально-етичних якостей, організація безперервного підвищення посадовими особами професійної компетентності засобами підвищення кваліфікації та самоосвіти, обміну досвідом.

Механізм реалізації конкретних завдань кадрової політики в органах місцевого самоврядування включає в себе розподіл завдань, функцій і повноважень між державними органами та структурами регіонального та місцевого рівнів щодо забезпечення поточної та стратегічної кадрової роботи.

Концепція державної кадрової політики повинна формувати основу, на якій розроблятимуться галузеві концепції, зокрема Концепція кадрової політики в органах місцевого самоврядування та програми кадрового забезпечення на місцевому рівні, які визначатимуть завдання на поточний та стратегічний етапи. Говорячи про визначення цілей, завдань та принципів здійснення кадрової політики в органах місцевого самоврядування, необхідно ще раз підкреслити іiі тісний взаємозв'язок $з$ державною кадровою політикою. У зв'язку з цим, заслуговує на підтримку думка С. Д. Дубенко про необхідність розробки для забезпечення єдності та комплексності кадрової політики їі концепції, яка б обгрунтувала цілі, стратегію формування та викори- 
стання кадрового корпусу. Концепція кадрової політики повинна стати iii теоретичною основою і включати в себе перш за все аналіз реального стану кадрового корпусу з визначенням перспективи розвитку, чітке визначення суб'єктів і об'єктів кадрової політики, їх взаємозв'язків і взаємовідносин у кадрових процесах i, зокрема, роль держави, відпрацювання вихідних ідей, що визначають мету і змістовні пріоритети кадрової політики, а також ії принципи; визначення пріоритетних (на найближчий час) і перспективних напрямків роботи з кадрами [4, с. 226-230]. Зазначена політика спрямована на визначення суб' єктів кадрової роботи, напрямів, механізмів та інструментів кадрового забезпечення реформ на місцевому рівні, ефективне використання професійного потенціалу посадових осіб, вироблення принципів політики, критеріїв для оцінювання та руху (мобільності) кадрів, стимулювання їх особистісно-професійного, морально-етичного, професійно-кваліфікаційного та професійно-посадового розвитку.

Потрібно налагодити чітку систему 3 дотриманням чиновниками антикорупційного законодавства.

Важливе значення має морально-етичний аспект службових відносин, який характеризує ставлення членів колективу органу місцевого самоврядування до виконання свого суспільного та громадянського обов'язку, ставлення до колективу і результатів спільної діяльності; а міжособистісні стосунки грунтуються та регулюються нормами моралі. Та найбільш суттєве й важливе у стосунках суб'єктів діяльності з точки зору ефективності управлінської діяльності та формування культури відносин мусить визначитися у правових професійних нормах. Вагоме місце в організації кадрової політики в органах місцевого самоврядування посідає внутрішня дисципліна, контроль, професіоналізм і персональна відповідальність керівників. Кожен 3 них повинен нести відповідальність за дії своїх підлеглих. Важливою формою реалізації цього положення є організація контролю у вигляді перевірок роботи працівників, окремих структурних підрозділів, сфер та напрямків діяльності посадових осіб.

Критерії ефективності контролю за реалізацією кадрової політики в органах місцевого самоврядування, організаційно-кадрової діяльності у сфері служби в органах місцевого самоврядування є одними 3 головних аспектів і напрямів іiї формування й реалізації. Серед них 
найбільш важливими критеріями оцінки ефективності місцевого управління є результативність, продуктивність, власне ефективність, якість і своєчасність, суспільна (громадська) підтримка.

Контроль за реалізацією кадрової політики в органах місцевого самоврядування - це проведення системних заходів щодо перевірки і спрямування ходу реалізації кадрової політики на місцях, аналіз результатів виконання документів у встановлені терміни. Контроль $є$ засобом систематичного й активного удосконалення роботи апарату управління в органах місцевого самоврядування. Необхідно забезпечити систематичний парламентський, судово-правовий, громадський, фінансовий контроль за здійсненням кадрової політики в органах місцевого самоврядування.

Надзвичайно проблемною сферою $є$ оплата праці посадових осіб місцевого самоврядування. На сьогодні вона слабко пов'язана 3 кваліфікацією кадрів, освітньою (професійно-кваліфікаційною) підготовкою та результатами навчання, складністю та відповідальністю виконуваних завдань тощо, а тим більше з загальною ефективністю діяльності владних структур. Рівень заробітної плати нижчий порівняно з іншими секторами економіки, хоча робота на службі в органах місцевого самоврядування вимагає високого професійного потенціалу, оперативності, ненормованого робочого дня.

\section{3. Реформування місцевого самоврядування у контексті} кадрового забезпечення органів місцевого самоврядування

Принципово нові вимоги та цілі, що стоять сьогодні перед сучасним управлінням місцевим і регіональним розвитком, вимагають високопрофесійних фахівців, здатних працювати в умовах, що інтенсивно змінюються, а це, відповідно, потребує розробки нового змісту навчання, спрямованого на нарощування професійного потенціалу працівників сфери місцевого самоврядування. Професійний потенціал - це та якість, на основі якої формується професійна придатність та компетентність, професіоналізм та професійна мобільність.

Сучасною наукою накопичено чимало тлумачень структури (змісту) поняття «кадровий потенціал», «професійний потенціал» по відношенню до професійної групи публічних службовців. «Професійний потенціал державних цивільних службовців є поняттям, що означає готовність и здатність державних цивільних службовців до ефективної професійної 
діяльності з забезпечення виконання повноважень державних органів, 3 метою забезпечення оптимальної життєдіяльності суспільства», - вказує Б. Д.-Д. Биликтуев [1]. Професійний потенціал державних службовців I. В. Поліщук складає з морально-психологічного, інтелектуального, творчого, комунікативного, лідерського, управлінського, кваліфікаційного, психофізіологічного потенціалів [14]. В основу структури кадрового (професійного) потенціалу посадових осіб місцевого самоврядування можна покласти типологізацію сфер професіоналізму [3; $5 ; 10 ; 16]$. Відтак, зазначена структура може включати в себе, наприклад, смисловий, проектувальний, мотиваційний, ціннісно-орієнтаційний; функціональний (операційний, діяльнісний, технологічний), регулятивний, корегувальний, забезпечувальний (ресурсний), комунікативний потенціали [13, с. 167], що разом складатимуть кадровий потенціал посадових осіб місцевого самоврядування як основу працездатності, професіоналізму та професійної мобільності. Зазначені компоненти наведених нами структур професійного потенціалу, а не тільки професійна компетентність (як нині), повинні покладатися в основу напрямів професійного розвитку та становлення персоналу органів влади України.

Поняття «посадова особа місцевого самоврядування» поєднує в собі згідно з соціально-професійним статусом п'ять основних груп працівників:

- «виборних керівників» - людей, що приймають рішення і які мають безпосередніх підлеглих, але які в залежності від способу призначення (через вибори) мають серед інших груп найвищий соціально-професійний статус, який, до речі, не завжди підтверджується найвищими показниками професійної компетентності та професіоналізму;

- «керівників, яких призначають» - людей, що приймають рішення і які мають безпосередніх підлеглих, і які мають нижчий соціально-професійний статус порівняно з виборними керівниками;

- «виконавців-1» - працівників, які мають підлеглих і безпосередніх начальників;

- «виконавців-2» - працівників, які не мають підлеглих, проте які мають безпосередніх начальників;

- «незалежних», депутатів місцевої ради, у яких немає ні начальників, ні підлеглих, або стосунки по вертикалі та горизонталі є частково формалізовані, або зовсім не формалізовані; або якщо депутати працюють в місцевій раді, то можуть мати і начальників і підлеглих [15]. 
Кадрове забезпечення в органах місцевого самоврядування в Україні має сприйматися як «моральна перебудова», «форма сучасного упорядкування професійної діяльності» посадових осіб місцевого самоврядування [8, с. 22-26], відмінними рисами якої в цілому $\epsilon$ моральність, лояльність та самоорганізація, ефективні процедури та інструменти професійної соціалізації. Професіоналізація посадових осіб місцевого самоврядування неможлива без здійснення функції контролю (всередині служби та ззовні) за процесом формування професіоналізму та професійної мобільності, необхідних особистих та ділових якостей кандидатів на посади, оскільки більшість проблем у процесі професіоналізації персоналу починається саме з його добору (відбору, підбору). Функція контролю є однією з найважливіших 3 позиції існування професійного інституту місцевого самоврядування як соціального ліфта, коли повинен забезпечуватися не рівний доступ на посади для всіх, а згідно з конкурсом на посади, коли перевага у доборі та кар'єрно-професійному просуванні віддаватиметься тим, хто має кращі здатності та здібності, професійний потенціал, а відтак потенційну професійну придатність.

Спеціальної уваги потребує удосконалення системи професійного навчання фахівців місцевого самоврядування, особливо щодо оптимізації співвідношення форм навчання та приведення його змісту до реальних потреб професійної діяльності [6, с. 230-233]. Основоположним питанням кадрової роботи посадових осіб місцевого самоврядування України $\epsilon$ використання системи безперервного навчання на основі акмеологічного, аскіологічного, андрагогічного, компетентнісного, діяльнісного підходів до професійної підготовки, розробка ключових компетентностей, видів управлінських операцій, технологій управління та оцінювання, необхідних для професійного зростання та вдосконалення.

Основним інституційним механізмом в удосконаленні професійного потенціалу публічного управління є національна система підготовки, перепідготовки та підвищення кваліфікації державних службовців та посадових осіб місцевого самоврядування. Система має набути гнучкості, здатності адаптуватися до нових завдань, що виникають в ході проведення політичної, адміністративної, муніципальної та інших реформ, поступового перерозподілу владних повноважень. Розвиток цієї системи спрямовується на гармонійне поєднання академічної (лекції та семі- 
нари) та тренінгової системи підготовки, залежність кар'єрного росту від професіоналізму та навчання, самоосвіти як засобів його забезпечення, дотримання європейських стандартів освіти та запровадження механізмів адаптації вітчизняної системи до європейської [12, с. 24].

Головним змістом підготовки, перепідготовки та підвищення кваліфікації посадових осіб місцевого самоврядування має стати навчання сучасним управлінським технологіям, новим методам і принципам здійснення управлінської діяльності, які не можуть бути засвоєними без глибоких теоретичних знань і володіння необхідними практичними вміннями та навичками [7]. Важливими напрямками подальшого підвищення ефективності системи професійної підготовки посадових осіб місцевого самоврядування є суттєве поглиблення диференціації та індивідуалізації навчання на базі послідовного вдосконалення організаційних структур цієї системи; впровадження сучасних освітніх технологій; розмежування підготовки кадрів різних управлінських рівнів за змістом і формами навчання, віддаючи перевагу денній формі; вдосконалення управління професійним навчанням посадових осіб місцевого самоврядування, посилення відповідальності органів місцевого самоврядування та керівників служб розвитку персоналу за професійний розвиток працівників.

Побудова сучасної моделі системи безперервного професійного розвитку та навчання повинна враховувати досвід централізованих (Німеччина, Велика Британія, Франція) та змішаних (Польща, Литва, Канада, США) підходів у частині забезпечення безперервності навчання, зокрема для муніципального сектору. Концепція моделі має грунтуватися на потребі у формуванні оновленої парадигми навчального процесу на принципах передачі та створення знань (науковий підхід до управління), спрямованості на формування знань, умінь та навичок роботи згідно зі стандартами публічної за характером та професійної за змістом та стандартами діяльності службовців. Зазначена система має працювати з використанням тренерського ресурсу з фахівців-практиків місцевого самоврядування, на застосуванні ринкових підходів і механізмів, що базуються на принципах забезпечення для клієнта різноманітності пропозицій та можливостях вибору, зручності для клієнта, гнучкого реагування на зміни навчально-консультаційних потреб, забезпечення високої якості та практичної цінності результатів навчання, моніторингу 
середовища та продукту, забезпечення зворотного зв'язку з випускниками [11, с. 261-262]. Необхідна також прозора система сертифікації навчальних закладів, що здійснюють професійне навчання посадових осіб місцевого самоврядування. Зараз в Україні можуть здійснювати підготовку за спеціальністю «Публічне управління та адміністрування» понад 130 закладів вищої освіти, що не створює конкурентного середовища, а навпаки - розпорошує науково-педагогічні кадри, наукові школи, негативно впливаючи на якість навчання.

Підвищення кваліфікації як вид навчання має ряд переваг порівняно з підготовкою та перепідготовкою: воно більш мобільне та здатне реагувати на політико-управлінські та соціально-економічні зміни, грунтується на андрагогічних принципах, має зв'язок з практичною діяльністю, дозволяє швидше набути нових навчальних компетенцій. Важливим завданням $є$ визначення ключових сучасних компетенцій для навчання, які можна поділити умовно на: теоретичні (базові); організаційно-правові основи місцевого самоврядування; муніципальний менеджмент; місцеві фінанси; стратегічні, програмно-цільові та менеджмент орієнтовані підходи в місцевому управлінні і т. д.) та специфічні (профільні) компетенції.

Запровадження постійно діючого визначення потреб органів місцевого самоврядування у підготовці, перепідготовці та підвищенні кваліфікації своїх працівників дасть можливість максимально адаптувати навчальні програми до потреб практики.

Розширення прав органів місцевого самоврядування, децентралізація державного управління об'єктивно призводитиме до того, що питома вага посадових осіб місцевого самоврядування в державному управлінні збільшуватиметься, а кількість державних службовців зменшуватиметься. Депутатський корпус місцевих рад $\epsilon$ найбільш проблематичним з точки зору визначення потреб у навчанні. Цей контингент слухачів має й матиме різний рівень базової освіти (від середньої школи до вищого навчального закладу, різні професійні та особисті потреби). Діяльність депутатів в місцевих радах України є позапрофесійною, що суттєво обмежує влив держави на формування іiі змісту та якості. Нормотворча діяльність депутатів рад має багатогалузевий та різноплановий характер, що ускладнює планування й проведення навчань, особливо короткотермінових. Виходом з ситуації можуть 
бути виїзні заняття з депутатами під час проведення сесій місцевих рад, інформаційні дні, активна самоосвіта депутатського корпусу за участю навчальних закладів з використанням дистанційних форм навчання.

Зміст і види підвищення кваліфікації управлінських кадрів необхідно наблизити до сучасної практики та зробити їх більш ефективними у вирішенні конкретних місцевих проблем. Посиленої уваги вимагає процес формування кадрового резерву, який, на жаль, недооцінений в нашій країні та ліквідований на державній службі. Процедура внесення посадової особи до кадрового резерву не повинна мати формальний характер, а формуватися з урахуванням науково обгрунтованих критеріїв під час професійного оцінювання кандидата, коли оцінюються управлінські здібності, соціально-психологічні якості, професійний потенціал, наявна та потенційна професійна мобільність в цілому.

В сенсі використання мотиваційного потенціалу важливим є оцінювання соціальних та професійних потреб, інтересів посадових осіб місцевого самоврядування, що можливе за умови створення регіональних центрів оцінювання, напрямами діяльності яких могли б бути: діагностика психічних якостей посадових осіб на всіх етапах їхнього професійного розвитку (також під час кадрового добору (відбору, підбору); професійне консультування; психокорекція та реабілітація.

Для створення умов для кадрового забезпечення місцевого самоврядування необхідно залучати міжнародну допомогу, використовуючи міжнародні проекти технічної допомоги в цій сфері.

Перспективним підходом у кадровій роботі вважається висування на керівні посади молодих працівників. 3 нашої позиції, молодість має поєднуватися з високим рівнем здібностей (научуваність, цілеспрямованість, культурність та етичність поведінки, потенціал), професійної компетентності, інших ділових та професійно мобільних якостей. У молоді часто спостерігається висока соціальна спрямованість на задоволення потреб у зв'язку, владарюванні шляхом роботи в управлінських структурах, органах влади. Анкетні опитування студентів закладів вищої освіти України найчастіше показують, що кожен третій (а з ряду молоді чоловічої статі кожен другий) студент хотів би в майбутньому бути керівником.

Отже, сьогодні потрібно робити розумну ставку на здібну до управлінської діяльності та ініціативну в бажанні реалізувати себе молодь. Сам 
вік не можна вважати синонімом професіоналізму та професійної мобільності людини. 3 метою підвищення ролі молоді в розбудові демократичного громадянського суспільства та системи публічного управління, iii активного залучення до служби в органи місцевого самоврядування, створення дієздатного кадрового потенціалу слід здійснювати перспективне планування потреби в кадрах органів місцевого самоврядування, наприклад, з числа кращих молодих громадських активістів, представників територіальної громади чи залучення молоді через зовнішні джерела (громадські організації, депутати рад, навчальні заклади, центри зайнятості). Дане питання $є$ досить актуальним, і лідери громад повинні на майбутнє планувати зовнішнє рекрутування та професійну освіту працівників виконкомів, виконавчих апаратів рад, депутатського корпусу.

Вимагає розширення та удосконалення завдання та функції діяльності служб з розвитку персоналу органів місцевого самоврядування. Окрім завдань та функцій аналізу та прогнозування ринку праці, реклами, пошуку та підбору персоналу, його оцінювання, організації навчання, вони повинні здійснювати професійний розвиток посадових осіб на системному підході, здійснюючи заходи з професійної орієнтації, адаптації, мотивування, активізації, виховання.

На сьогодні органи місцевої влади покликані забезпечити надання адміністративних послуг в найкращий до громадянина спосіб. Покращити зазначену ситуацію може широке співробітництво державного та недержавного, неприбуткового секторів. Громадські організації, згідно із законодавством України, слід розуміти й розглядати не окремим ізольованим елементом демократії, а формою, способом безпосередньої участі громадян в управлінні, органічним та невід'ємним елементом системи місцевого самоврядування, зокрема в питаннях, що стосується формування професійної компетентності та навчання посадових осіб місцевого самоврядування.

Для покращення якості навчання та обміну професійним досвідом посадових осіб місцевого самоврядування актуально зміцнювати роль національних асоціацій, добровільних об'єднань органів місцевого самоврядування необхідності залучення асоціацій органів місцевого самоврядування до розробки та здійснення навчання депутатів та муніципальних службовців без відриву від виробництва, оскільки це суттєво покращить результати професіоналізації. 
Таким чином, якісне кадрове забезпечення неможливе без створення сприятливих умов для самореалізації особистості та професіоналізації служби в органах місцевого самоврядування України. Найголовніші проблеми в процесі професіоналізації зазначеного виду професійної діяльності пов'язані з досить складною професійною структурою посад та посадових компетенцій, яка у свою чергу потребує системного підходу не лише до професійної підготовки, а для всіх напрямів особистісно-професійного, морально-етичного, професійно-посадового, професійно-кваліфікаційного розвитку управлінських кадрів місцевого самоврядування (професійних орієнтації, адаптації, мотивації, оцінювання, активізації, виховання, які повинні мати інституційне забезпечення та здійснюватися керівниками).

\section{4. Висновки}

Таким чином, удосконалення кадрової політики в органах місцевого самоврядування України повинно проводитися, перш за все, із урахуванням перспективних завдань державної політики в цілому та iї складової - кадрової політики в органах місцевого самоврядування.

Необхідно вдосконалити форми і методи роботи з посадовими особами місцевого самоврядування, резервом кадрів, задіяти механізми i принципи формування і реалізації кадрової політики в органах місцевого самоврядування, створити для цього організаційні умови, вирішити питання раціонального добору, розстановки і професійно-посадового розвитку кадрів шляхом комплексного оцінювання персоналу, зокрема професійного потенціалу, включаючи діяльнісне вираження останнього. Слід передбачити докорінні зміни у змісті підготовки, перепідготовки й підвищення кваліфікації, самоосвіті посадових осіб місцевого самоврядування, які б відповідали новим повноваженням та компетенції органів місцевого самоврядування, базувались на професійному потенціалі та придатності, спрямовуючись на досягнення високого професіоналізму, професійної мобільності, включаючи управлінські здібності й високу професійну культуру.

На підставі зроблених досліджень запропоновано основні шляхи удосконалення кадрової роботи в органах місцевого самоврядування України:

- передбачити в чинному законодавстві норми щодо політичної нейтральності посадових осіб місцевого самоврядування, професій- 
но-кваліфікаційні вимоги до кандидатів на посади, що заповнюються за конкурсною процедурою;

- створити виїзні заняття з посадовими особами та депутатами місцевих рад під час проведення сесій рад, інформаційні дні, умови для самоосвіти за участю навчальних закладів з використанням дистанційних форм навчання;

- зміст і види підвищення кваліфікації управлінських кадрів місцевого самоврядування необхідно наблизити до сучасної практики та зробити їх більш ефективними у вирішенні конкретних проблем;

- вдосконалити форми та методи кадрової роботи з посадовими особами місцевого самоврядування, резервом кадрів, задіяти механізми і принципи формування і реалізації кадрової політики в органах місцевого самоврядування, створити для цього організаційні умови, вирішити питання раціонального добору (відбору, підбору), адаптації, мотивації, активізації, оцінювання, виховання, розстановки та використання кадрів;

- продовжити роботу з удосконалення системи соціального захисту та оплати праці, запровадити диференціацію оплати праці залежно від кваліфікації кадрів, рівня освіти, результатами навчання, складності виконуваних завдань;

- створити систему об’єктивної оцінки діяльності посадових осіб, яка має включати комплексну оцінку професійного потенціалу, професіоналізму, професійної мобільності, або: рівня професійної компетентності; продуктивності та якості роботи; організаторських та комунікативних здібностей; здатності до самореалізації та самовдосконалення;

- посилити соціальний захист працівників органів місцевого самоврядування та їх захист від залучення до виборчих компаній, від необгрунтованих звільнень, зокрема в тих випадках, коли відбуваються переобрання політиків до керівництва органів місцевого самоврядування;

- створити систему контролю за кадровими процесами в органах місцевого самоврядування.

3 нашої позиції варто передбачати виділення в місцевих бюджетах коштів на підвищення кваліфікації муніципальних службовців у розмірі не менше 4 \% від фонду заробітної плати. Також потрібно посилити захист посадових осіб місцевого самоврядування від залучення 
до виборчих компаній, від необгрунтованих звільнень посадових осіб, зокрема в таких випадках, коли відбувається оновлення політиків та керівництва органів місцевого самоврядування.

\section{Список літератури:}

1. Биликтуев Б. Д.-Д. Профессиональный потенциал государственных гражданских служащих в современной России: на материалах Республики Бурятия : дис. ... канд. социол. н. : 22.00 .04 - социальная структура, социальные институты и процессы / Биликтуев Буянто Даши-Доржиевич; Бурятский гос. ун-т. Улан-Удэ, 2009. 167 c. URL: http://www.dissercat.com/content/professionalnyipotentsial-gosudarstvennykh-grazhdanskikh-sluzhashchikh-v-sovremennoi-rossii

2. Гендерний аналіз українського суспільства / за ред. Т. Мельник. Київ : ПРООН, 1999. 293 с.

3. Дружилов С. А. Профессиональная компетентность и профессионализм педагога: психологический подход / Сибирь. Философия. Образование: научно-публицистический альманах. Новокузнецк : СО РАО, ИПК, 2005. Вып. 8. С. 26-44.

4. Дубенко С. Державна кадрова політика в регіонах. Вісник УАДУ. 2001. № 3. С. 226-230.

5. Казарян М. Ю. Особенности социальных представлений о профессионализме. 2-я междунар. науч. интернет-конф. «Профессиональное самосознание и экономическое поведение личности». URL: http://konfep.narod.ru/kazar.htm

6. Козюра I. Навчання депутатів місцевих рад (досвід Канади). Вісник УАДУ. 2002. № 3. С. 230-233.

7. Краснопьорова С. В. Методологічні пролегомени професіоналізації служби в органах місцевого самоврядування. Актуальні проблеми державного управління : зб. наук. пр. Харків : ХаРІДУ НАДУ, 2007. № 2. С. 309-317.

8. Лавриненко Д. Испытание при приеме на работу отдельных категорий служащих. Бизнес Информ. 2006. № 13. С. 22-26.

9. Майстро С. В. Розмежування повноважень органів державної влади та органів місцевого самоврядування. Державне будівнищтво. 2012. № 1. URL: http://nbuv.gov.ua/UJRN/DeBu_2012_1_33

10. Маркова А. К. Психология професссионализма. Москва : Знание, 1996. 306 с.

11. Мельников О. Значущість рівня підготовки державних службовців для ефективної роботи організації та службового зростання ії співробітників. Вісник УАДУ. 2006. № 1. С. 261-262.

12. Науково-методологічне забезпечення формування кадрового потенціалу місцевого самоврядування в Україні: наук. розробка / авт. кол.: І. В. Козюра, О. О. Бабінова, Я. Ф. Жовнірчик та ін. / за заг. ред. Ю. П. Сурміна, І. В. Козюри. Київ : НАДУ, 2010. 40 с.

13. Незять В. І. До проблеми структури кадрового потенціалу посадових осіб місцевого самоврядування. Теорія та практика публічної служби : матеріали наук.-практ. конф. (Дніпро, 21 груд. 2018 р.) / за заг. ред. С. М. Серьогіна. Дніпро : ДРІДУ НАДУ, 2018. С. 164-167. 
14. Поліщук I. В. Механізми забезпечення розвитку професійного потениіалу державних службовиів в Україні : автореф. дис. ... канд. держ. упр : 25.00.02 - механізми держ. упр.; НАДУ. Київ : НАДУ, 2018. 20 с.

15. Шпекторенко I. В. Функції та принципи управління у трансформації соціально-професійного статусу посадової особи місцевого самоврядування в Україні. Публічне адміністрування: теорія та практика : ел. зб. наук. пр. ДРІДУ. 2018. Вип. 1(19). URL: http://www.dridu.dp.ua/zbirnik/2018-01(19)/17.pdf

16. Шпекторенко І. Підходи до професійної мобільності державного службовця в сучасних концепціях професіоналізації. Державне управління та місиеве самоврядування : зб. наук. пр. ДРІДУ. Вип. 3(30). Дніпро : ДРІДУ НАДУ, 2016. C. 126-133.

17. Яковенко О. Кадровий потенціал державотворення: стан та проблеми розвитку. Вісник УАДУ. 2002. № 1. С. 19-26.

\section{References:}

1. Biliktuev B. D.-D. (2009). Professional'nyy potentsial gosudarstvennykh grazhdanskikh sluzhashchikh $v$ sovremennoy Rossii: na materialakh Respubliki Buryatiya [Professional potential of civil servants in modern Russia: on the materials of the Republic of Buryatia]. (PhD), Ulan-Ude: Buryat state university, $167 \mathrm{p}$. Retrieved from: http://www.dissercat.com/content/professionalnyi-potentsial-gosudarstvennykh-grazhdanskikh-sluzhashchikh-v-sovremennoi-rossii

2. Ghendernyj analiz ukrajinsjkogho suspiljstva [Gender analysis of Ukrainian society] / eds. T. Meljnyk (1999). Kyiv: PROON, 293 p. (in Ukrainian).

3. Druzhilov S. A. (2005). Professional'naya kompetentnost' $i$ professionalizm pedagoga: psikhologicheskiy podkhod [Professional competence and professionalism of a teacher: a psychological approach] / Sibir'. Filosofiya. Obrazovanie: nauchnopublitsisticheskiy al'manakh. Novokuznetsk: SO RAO, IPK, vol. 8, pp. 26-44.

4. Dubenko S. (2001). Derzhavna kadrova polityka v reghionakh [State personnel policy in the regions]. Visnyk UADU [Bulletin of the UAPA], no. 3, pp. 226-230.

5. Kazaryan M. Yu. Osobennosti sotsial'nykh predstavleniy o professionalizme [Features of social ideas about professionalism]. Proceedings of the 2-ya mezhdunar. nauch. internet-konf. «Professional'noe samosoznanie i ekonomicheskoe povedenie lichnosti». Retrieved from: http://konfep.narod.ru/kazar.htm

6. Kozjura I. (2002). Navchannja deputativ miscevykh rad (dosvid Kanady) [Training of local council members (Canadian experience)]. Visnyk UADU [Bulletin of the UAPA], no. 3, pp. 230-233.

7. Krasnopjorova S. V. (2007). Metodologhichni proleghomeny profesionalizaciji sluzhby v orghanakh miscevogho samovrjaduvannja [Methodological prolegomens of professionalization of service in local self-government bodies]. Aktualjni problemy derzhavnogho upravlinnja [Actual problems of public administration]: zb. nauk. pr. Kharkiv: KhaRIDU NADU, no. 2, pp. 309-317.

8. Lavrinenko D. (2006). Ispytanie pri prieme na rabotu otdel'nykh kategoriy sluzhashchikh [Test for hiring certain categories of employees]. Biznes Inform [Business Inform], no. 13, pp. 22-26. 
9. Majstro S. V. (2012). Rozmezhuvannja povnovazhenj orghaniv derzhavnoji vlady ta orghaniv miscevogho samovrjaduvannja [Separation of powers of state authorities and local governments]. Derzhavne budivnyctvo [State building], no. 1. Retrieved from: http://nbuv.gov.ua/UJRN/DeBu_2012_1_33

10. Markova A. K. (1996). Psikhologiya professionalizma [Psychology of professionalism]. Moskow: Znanie, 306 p. (in Russian)

11. Meljnykov O. (2006). Znachushhistj rivnja pidghotovky derzhavnykh sluzhbovciv dlja efektyvnoji roboty orghanizaciji ta sluzhbovogho zrostannja jiji spivrobitnykiv [Significance of the level of training of civil servants for the effective work of the organization and the career growth of its employees]. Visnyk NADU [Bulletin of the NAPA], no. 1, pp. 261-262.

12. Naukovo-metodologhichne zabezpechennja formuvannja kadrovogho potencialu miscevogho samovrjaduvannja v Ukrajini [Scientific and methodological support for the formation of human resources potential of local self-government in Ukraine]: nauk. rozrobka (2010) / eds.: Ju. P. Surmin, I. V. Kozjura. Kyiv: NADU, 40 p. (in Ukrainian)

13. Nezjatj V. I. (2018). Do problemy struktury kadrovogho potencialu posadovykh osib miscevogho samovrjaduvannja [To the problem of the structure of human resources of local government officials]. Proceedings of the Teorija ta praktyka publichnoji sluzhby: materialy nauk.-prakt. konf. (Dnipro, 21 ghrud. 2018 r.) / eds. S. M. Serjoghin. Dnipro: DRIDU NADU, pp. 164-167.

14. Polishhuk I. V. (2018). Mekhanizmy zabezpechennja rozvytku profesijnogho potencialu derzhavnykh sluzhbovciv v Ukrajini [Mechanisms for ensuring the development of professional potential of civil servants in Ukraine] (PhD Thesis), Kyiv: NADU, $20 \mathrm{p}$.

15. Shpektorenko I. V. (2018). Funkciji ta pryncypy upravlinnja u transformaciji socialjno-profesijnogho statusu posadovoji osoby miscevogho samovrjaduvannja v Ukrajini [Functions and principles of management in the transformation of the socio-professional status of a local government official in Ukraine]. Publichne administruvannja: teorija ta praktyka [Public administration: theory and practice]: el. zb. nauk. pr. DRIDU, vol. 1(19). Retrieved from: http://www.dridu.dp.ua/ zbirnik/2018-01(19)/17.pdf

16. Shpektorenko I. (2016). Pidkhody do profesijnoji mobiljnosti derzhavnogho sluzhbovcja v suchasnykh koncepcijakh profesionalizaciji [Approaches to professional mobility of civil servants in modern concepts of professionalization]. Derzhavne upravlinnja ta misceve samovrjaduvannja [Public administration and local self-government]: zb. nauk. pr. DRIDU, vol. 3(30). Dnipropetrovsk: DRIDU NADU, pp. 126-133.

17. Jakovenko O. (2002). Kadrovyj potencial derzhavotvorennja: stan ta problemy rozvytku [Personnel potential of state formation: state and problems of development]. Visnyk UADU [Bulletin of the UAPA], no. 1, pp. 19-26. 